\title{
$\mathrm{N}_{2}$ ガス直流グロー放電プラズマの精密な振動温度の 分光学的診断法とその適用
}

\author{
正員 西 嶋 喜代人（福岡大） \\ 正員水田佳男 (福岡大)
}

\section{An Accurate Diagnostic Method with Emission Spectroscopy on Vibrational Temperatures and its Application for DC-Glow Discharge Plasma in $\mathrm{N}_{2}$ Gas Kiyoto Nishijima, Member, Yoshio Mizuta, Member (Fukuoka University)}

More accurate measurement of the vibrational temperature for a DC-glow discharge plasma with $\mathrm{N}_{2}$ gas has been attempted using the spectroscopic diagnostics. The vibrational temperatures were determined from vibrational intensity distributions of the second positive system bands (the $C^{3} \Pi u \rightarrow B^{3} \Pi g$ emissions, $\left.\Delta v=-2\right)$ in $\mathrm{N}_{2}$ spectra. These vibrational distribution of the spectrum system have also been adjusted in the present calculations so as to fit experimental spectral intensity and theoretical spectral intensity which depend on rotational temperature and gas pressure. From this diagnosis, the errors associated with the measured vibrational temperature are estimated to be of the order of $6 \%$. However, the present developed diagnosis has also been applied to measure the vibrational temperatures of a negative glow region with the discharge current density on DC-glow discharge plasma in $\mathrm{N}_{2}$ gas.

キーワード：直流グロー放電, $\mathrm{N}_{2}$ ガス, 振動温度, 分光学的診断

\section{1. まえがき}

$\mathrm{N}_{2}$ ガスを含む気体放電は， $\mathrm{CO}_{2}$ レーザ， $\mathrm{N}_{2}$ レーザ また空気を原料とするオゾナイザなどに利用されると 共に, 空気の絶縁破壊メカニズムとも関連する。なか でも， $\mathrm{N}_{2}$ ガス直流グロー放電プラズマは， $\mathrm{N}_{2}$ の基底 電子準位の振動励起によって, その電気伝導機構が影 響(1)を受け，放電相転移(2)を生じる。

著者らの一連研究(3)(4) は, 数 Torr 以上の気体圧力 での直流グロー放電に関して精密な回転温度 $\left(\mathrm{N}_{2}\right.$ 分 子の並進運動と回転運動がエネルギー平衡を達成して いる条件下では気体温度）と振動温度を分光学的に診 断する技術の確立に向けられた。特に, 振動温度の分 光学的診断法 ${ }^{(5)} に は$, 気体圧力と回転温度とを考慮す る必要があることが判明した。

本研究では, $\mathrm{N}_{2}$ の 2nd positive systemバンドの放 射スペクトル強度分布に与える気体圧力と回転温度の
依存性を数值解析で明らかにすると共に，実測したス ペクトル強度分布とも比較している。その結果, 回転 温度と気体王力に依存するスペクトル強度分布の解析 と実測の一致が良いことが確認された。また，本分光 学的振動温度の診断法は, $\mathrm{N}_{2}$ ガス直流グロー放電プ ラズマの負グロー領域に適用され，放電電流密度の上 昇に伴う振動温度の增大を明らかにした。

なお，提案した振動温度の診断法は，同一放電条件 下での測定誤差が約 $6 \%$ 以下であり，放電パラメータ の変化に伴うプラズマ状態を十分に把握できるものと 考兑られる。

\section{2. 精密な振動温度の診断法}

$\mathrm{N}_{2}$ の 2nd positive system バンドの $(0,2)$ 系列を使 った振動温度 $T_{\nu}$ の導出法は, Bleekrode ${ }^{(6)}$ の方法を 基本的に用いているが, 次の点に改良を加えた。

(1) $\mathrm{N}_{2}$ の 2nd positive system バンドの $(0,2)$ 系 
列の $(0,2)$ と $(2,4)$ 遷移で回転スペクトル強度分布 のピーク値の比を利用する。

（2）分光器を含めたスペクトル検出系でのスペク トル広がりの効果を装置関数で考慮する。

(3) $T_{v}$ 計測に与える回転温度 $T_{r}(\fallingdotseq$ 気体温度 $T_{g}$ )の効果を考慮する。

（4） $C^{3} I u$ の各振動単位の励起分子数密度に与之 る気体圧力 $P$ に依存したクエンチング効果と上位振 “動準位からのスケード励起を考慮する。

〈2・1〉 $\mathrm{N}_{2}$ の 2nd positive systemバンド $(0,2)$ 系 列の理論スペクトル強度 $\quad \mathrm{N}_{2}$ の 2nd positive system バンド $(0,2)$ 系列の理論的スペクトル強度を導出 するには, 図1に示した $\mathrm{N}_{2}$ 分子の電子励起準位と各 準位間の遷移過程を考慮することが必要である。導出 する振動温度 $T_{v}$ は， $\mathrm{N}_{2}$ の電子基底準位 $X^{1} \Sigma g^{+}$の各 振動準位 $v(v=0 \sim 11$ を考慮 $)$ に対する励起分子密度 $N_{v}$ の分布と関係する。ここで， $N_{v}$ の值は Boltzmann 則に従う $T_{v}$ の関数として仮定する。従って, $N_{v}$ は $X^{1} \Sigma g^{+}$の全分子数密度が与えられると， $T_{v}$ の 関数として計算される。

次に, $X^{1} \Sigma g^{+}$の各振動準位の励起分子は, 電子の 衝突励起により $C^{3} \Pi u$ へ遷移する。このときのフラ ンタコンドン係数に関係した相対遷移確率 $A_{v v^{\prime}}$ は,

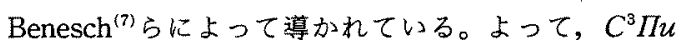
の各振動準位 $v^{\prime}$ へ単位時間あたり電子によって励起 される相対的分子数密度 $N_{v}{ }^{\prime}\left(T_{v}\right)$ は次式で与えら

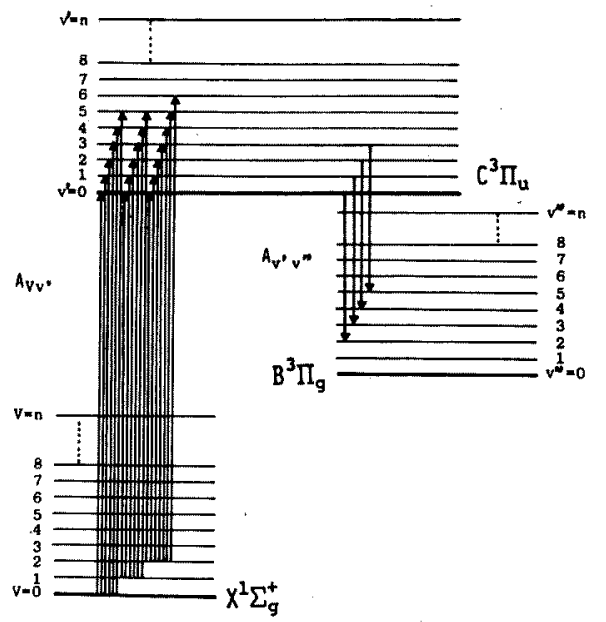

図 $1 \mathrm{~N}_{2}$ 分子の電子準位と振動レベルの 概略図と電子遷移過程

Fig. 1. A schematic diagram of electronic states and vibrational levels of $\mathrm{N}_{2}$ molecule and electron transition process between each levels.
れる。

$$
\begin{aligned}
& N_{v}^{\prime}\left(T_{v}\right)=\nu_{e x} \sum_{v=0}^{11} A_{v v^{\prime}} N_{v} \cdots \cdots \cdots \cdots \cdots \cdots \cdots \cdots(1 \\
& \text { ここで, } \nu_{e x}: X^{1} \Sigma g^{+} \text {から } C^{3} \Pi u へ の \text { 電子の } \\
& \text { 洏起周波数であり, 電子エネルギーに依存す } \\
& \text { る量 }
\end{aligned}
$$

(1)式の計算により, $C^{3} \Pi u$ の $v^{\prime}=0,1,2,3$, の各々 の相対励起分子密度 $N_{0}, N_{1}, N_{2}, N_{3}$ が導出される。

一方, $C^{3} \Pi u の N v^{\prime}\left(T_{v}\right)$ は, この電子準位の振動温 度を $T_{v}^{\prime}$ と仮定できれば， $X^{\mathrm{I}} \Sigma g^{+}$と同様に Boltzmann 則にしたがう。このことは, 例えば $N_{0}$ と $N_{2}$ の相対励起分子数密度比が次の関数を満たすことを意 味する。

$$
\frac{N_{2}}{N_{0}}=\frac{\exp \left(-E_{2} / k T_{v}{ }^{\prime}\right)}{\exp \left(-E_{0} / k T_{v}^{\prime}\right)}
$$

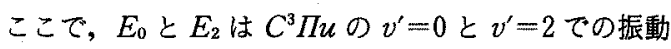
エネルギーで既知量であり，また $k$ は Boltzmann定 数である。(2)式から， $N_{2} / N_{0}$ 比は $T_{v}^{\prime}$ の関数であ

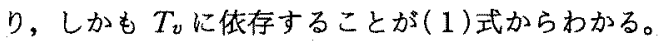
この $N_{0}$ と $N_{2}$ を直接実測できるならば, (1)と (2) 式から $T_{v}$ と $T_{v}{ }^{\prime}$ を導出することが可能となる。しか しながら， $N_{0}$ と $N_{2}$ の直接的な実測ができないことか ら, $N_{2}$ と $C^{3} \Pi u$ から $B^{3} \Pi g$ への遷移に伴う強い発光 の 2nd positive system バンド $(0,2)$ 系列のスペクト 儿強度が利用される。

$C^{3} \Pi u\left(v^{\prime}\right) \rightarrow B^{3} \Pi g\left(v^{\prime \prime}\right)$ 遷移（図 1 参照）に伴う相対 理論スペクトル強度 ${ }^{(6)} I_{v^{\prime} v^{\prime \prime}}\left(\lambda_{0}\right)$ は，著者らの精密な相 対回転スペクトル強度 ${ }^{(3)} I_{\mathrm{rot}}\left(\lambda_{0}, T_{\tau}\right)$ を用いると次式で 与竞られる。

$$
\begin{aligned}
& I_{v^{\prime} v^{\prime \prime}}\left(\lambda_{0}\right)=N_{v^{\prime}}\left(T_{v}\right) A_{v^{\prime} v^{\prime \prime}} h \nu I_{\text {rot }}\left(\lambda_{0}, T_{r}\right) \cdots(3) \\
& \text { ここで， } \lambda_{0} \text { : 計測されるスペクトル波長で, } \\
& A_{v}{ }^{\prime} v^{\prime \prime}: C^{3} \Pi u \rightarrow B^{3} \Pi g \text { 遷移に伴う相対遷移確 }
\end{aligned}
$$

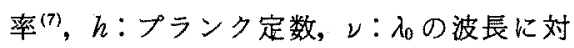

$$
\begin{aligned}
& \text { 応するスペクトルの周波数 }
\end{aligned}
$$

〈2・2〉気体圧力による相対理論スペクトル強度の 変化 (3)式での $I_{v^{\prime}} v^{\prime}\left(\lambda_{0}\right)$ は, $N_{v^{r}}\left(T_{v}\right)$ の放射解消 のみで決定されることを意味する。しかし， $\mathrm{N}_{2}\left(C^{3} \Pi u\right) v^{\prime}$ の励起分子は, 高い気体圧力のもとでは $N_{2}\left(X^{1} \Sigma g^{+}\right)$との衝突によって振動励起解消や電子励 起クエンチングにより他の励起準位へ放射を伴わず遷 移する。な拉, $N_{2}\left(C^{3} I I u\right) v^{\prime}$ と電子との衝突による励 起解消は, 各々の粒子の密度が小さいことから考慮し ていない。これらのクエンチング過程 ${ }^{(8)}$ は, 表 1 に示 すように放射解消係数 $K_{r 0}^{\prime}$ ，振動解消係数 $K_{v v}{ }^{\prime}$ そし て電子励起クエンチング係数 $K_{e v}{ }^{\prime}$ をもことが $\mathrm{N}_{2}$ ガ スについて実測されている。そこで，C $C^{3} \Pi u の$ 各振動 
表 $1 \mathrm{~N}_{2}\left(\mathrm{C}^{3} \Pi u\right)$ の解消反灾係数

Table 1. Deactivation rate of the $N_{2}\left(C^{3} \Pi u\right)$.

\begin{tabular}{l|l|l|l}
\hline$v^{\prime}=3$ & $K_{r 2}\left(K_{r 3}\right)$ & $K_{e 2}\left(K_{e 3}\right)$ & $K_{V 2}\left(K_{V 3}\right)$ \\
$v^{\prime}=2$ & $2.4 \times 10^{-2}$ & $8.5 \times 10^{-4}$ & $3.6 \times 10^{-4}$ \\
& $\left(\mathrm{~ns}^{-1}\right)$ & $\left(\mathrm{ns}^{-1} \cdot \mathrm{Torr}^{-1}\right)$ & $\left(\mathrm{ns}^{-1} \cdot \mathrm{Torr}^{-1}\right)$ \\
\hline$v^{\prime}=1$ & $K_{r 1}$ & $K_{e 1}$ & $K_{V 1}$ \\
& $2.2 \times 10^{-2}$ & $3.1 \times 10^{-4}$ & $5.4 \times 10^{-4}$ \\
& $\left(\mathrm{~ns}^{-1}\right)$ & $\left(\mathrm{ns}^{-1} \cdot\right.$ Torr $\left.^{-1}\right)$ & $\left(\mathrm{ns}^{-1} \cdot \operatorname{Torr}^{-1}\right)$ \\
\hline$v^{\prime}=0$ & $K_{r 0}$ & $K_{e 0}$ & \\
& $2.4 \times 10^{-2}$ & $4.3 \times 10^{-4}$ & \\
& $\left(\mathrm{~ns}^{-1}\right)$ & $\left(\mathrm{ns}^{-1} \cdot\right.$ Torr $\left.^{-1}\right)$ & \\
\hline
\end{tabular}

準位 $v^{\prime}=0 \sim 3$ にある励起分子のうち $B^{3} \Pi g$ の電子準 位へ放射を伴って遷移する割合を計算するため, 気体 圧力 $P_{\mathrm{N}}$ に依存したクエンチングファクタ $\phi_{q v}{ }^{\prime}$ を導出 した。すなわち， $\phi_{q v}{ }^{\prime}$ は定常状態を仮定して反応レ一 卜方程式加ら導出でき，具体的には， $v^{\prime}=0 \sim 3$ の準 位注対する $\phi_{q v}{ }^{\prime}$ は各々次式で与えられる。

$$
\begin{aligned}
& v^{\prime}=2, v^{\prime}=3 \text { について： } \\
& \phi_{q 2}=\phi_{q 3}=\frac{K_{r 2}}{K_{r 2}+K_{e 2} P_{\mathrm{N}}+K_{v 2} P_{\mathrm{N}}} \\
& v^{\prime}=1 \text { について： } \\
& \phi_{q 1}=\left(1+\frac{N_{2}}{N_{1}} \frac{K_{v 2} P_{\mathrm{N}}}{K_{r 2}+K_{e 2} P_{\mathrm{N}}+K_{v 2} P_{\mathrm{N}}}\right) \\
& \times\left(\frac{K_{r 1}}{K_{r 1}+K_{e 1} P_{\mathrm{N}}+K_{v 1} P_{\mathrm{N}}}\right) \\
& \phi_{q 0}=\left\{1+\left(\frac{N_{1}}{N_{0}}+\frac{N_{2}}{N_{1}} \frac{K_{v 2} P_{\mathrm{N}}}{K_{\tau 2}+K_{e 2} P_{\mathrm{N}}+K_{v 2} P_{\mathrm{N}}}\right)\right. \\
& \left.\times\left(\frac{K_{v 1} P_{\mathrm{N}}}{K_{r 1}+K_{e 1} P_{\mathrm{N}}+K_{v 1} P_{\mathrm{N}}}\right)\right\} \\
& \times\left(\frac{K_{T 0}}{K_{r 0}+K_{e 0} P_{\mathrm{N}}}\right)
\end{aligned}
$$

ここで, $P_{\mathrm{N}}: \mathrm{N}_{2}$ ガスの $20^{\circ} \mathrm{C}$ 換算気体圧力

(Torr)

従って，クエンチングファタタを考慮した相対理論 スペクトル強度 $I_{q v^{\prime} v^{\prime \prime}}\left(\lambda_{0}\right)$ は，(3) 式を用いて次式で 表される。

$$
I_{q v^{\prime} v^{\prime \prime}}\left(\lambda_{0}\right)=\phi_{q v^{\prime}} I_{v^{\prime} v^{\prime \prime}}\left(\lambda_{0}\right)
$$

〈2・3〉実測される相対スペクトル強度実測さ れる線スペクトルは, 分光器を含むスペクトル検出系 および放電プラズマ(9)のスペクトル線広がり効果とが 関係する。促って，実測されるスペクトル強度を精密 に評価するには，単一スペクトの広がりに関係した装 置関数の実測が不可欠である。

本研究の分光学的診断で用いられるスペクトルの検

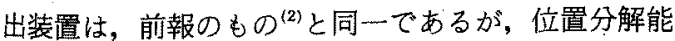

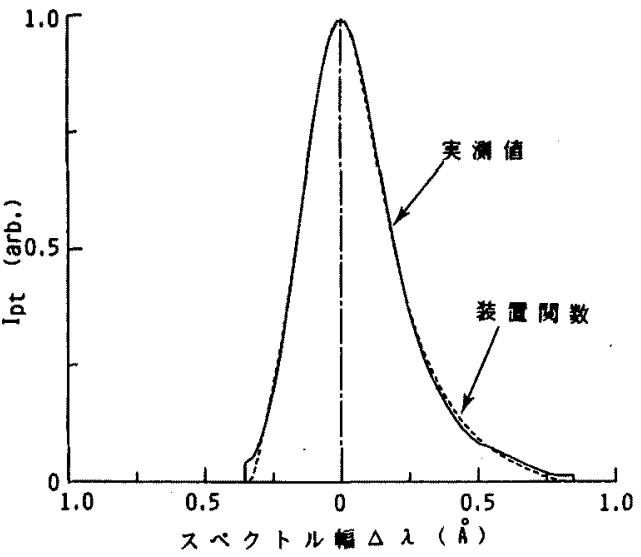

図 2 線スペクトルの広がり

Fig. 2. The measured and approximated line shapes for a rotational line.

とデータ処理の改善を図るために, 高精度位置決め $X-Y$ テブル（最小駆動単位 $5 \mu \mathrm{m}$ ）とマイクロコ ンピュータ (4)を付加している。本実験での更正用の線 スペクトルは，波長同定が容易な $\mathrm{N}_{2}^{+}$1st negative systemバンド $(0,0)$ の回転スペクトル $(R$ 技，回転 量子数 $J=13)$ である。このスペクトルの強度分布を 入カスリット幅 $50 \mu \mathrm{m}$ の逆分散 $4.8 \AA / \mathrm{mm}$ の分光器 を用いて計測した結果が図 2 に示される。実測された 強度分布の形状（同図中の実線）と一致する装置関数 を導出すると, Phillipsの関数(10)で表されることが判 明した。従って，本研究の解析で用いられた装置関数 $g(\Delta \lambda)$ は， $\lambda_{0}$ の中心波長に対して左側の部分において スペクトル半值幅 $W=0.33 \AA$ そしてすを広がり $S=$ $0.33 \AA$ とし, 右側の部分に执いて $W=0.40 \AA$ ，そし て $S=0.82 \AA$ として与えられた。なお, 図 2 の形状 の左右の非対称性は実測における調整によって取除く ことができなかった。

以上のことから，実測されるであろう理論スペクト 儿強度 $\tilde{I}_{v^{\prime} v^{\prime \prime}}\left(\lambda_{0}\right)$ は，(7)式のスペクトル強度に装置 関数 $g(\Delta \lambda)$ を乗じたものとなり，次式で与えられる。

$$
\widetilde{I}_{v^{\prime} v^{\prime \prime}}\left(\lambda_{0}\right)=g(\Delta \lambda) I_{q v^{\prime} v^{\prime \prime}}\left(\lambda_{0}\right)
$$

上式は， $\mathrm{N}_{2}$ の 2nd positive systemバンド $(0,2)$ 系列 の波長範囲 $3,640 \sim 3,810 \AA$ で数値解析される。よっ て, 解析結果の相対スペクトル強度分布は, $T_{\tau}, T_{v}$ そして封入気体圧力 $P\left(=P_{\mathrm{N}} T_{r} / 293\right)$ をパラメータと した波長の関数で表示される。

〈2・4〉振動温度の計測法 $\mathrm{N}_{2} の X^{1} \Sigma g^{+}$準位の 振動励起分子数密度分布は, 高い振動温度では振動励 起分子同士でのエネルギー交換や電子，分子との衝突 


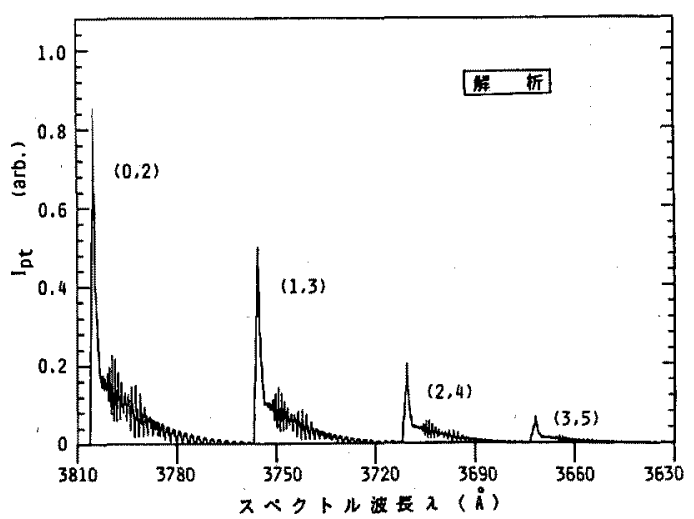

図 $3 \mathrm{~N}_{2}$ の 2nd positive systemバンド $(0,2)$ 系列のスペクトル強度分布の解析值

Fig. 3. Calculated intensity distribution of $\mathrm{N}_{2}$ 2nd positive system bands at $v^{\prime}-v^{\prime \prime}$ $=-2$.

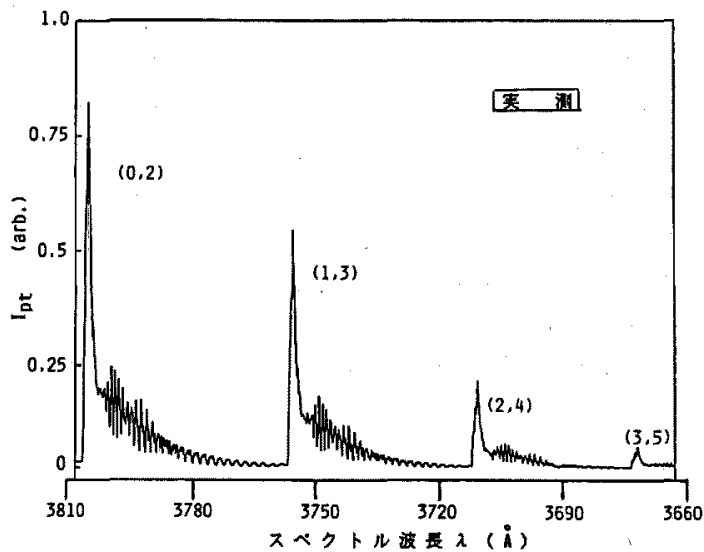

図 $4 \mathrm{~N}_{2}$ の 2nd positive systemバンド $(0,2)$ 系列のスペクトル強度分布の実験值

Fig. 4. Observed intensity distribution of $\mathrm{N}_{2}$ 2nd positive system bands at $v^{\prime}-v^{\prime \prime}=$ -2 .

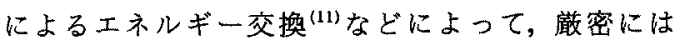
Boltzmann 分布とはならない。しかし，振動エネル ギーの小さい $v=0 \sim 3$ の振動準位の分子数密度分布 は，ほほBoltzmann 分布に近いことが, Loureiro ら の解析 ${ }^{(11)}$ 結果から仮定できる。従って，この低い振 動準位の励起分子数密度分布を使って導出された $T_{v}$ は，廠密な意味での振動温度でなく特性振動温度と呼 ばれるものである。

図 3 は封入気体压力 $P=30$ Torr, $T_{r}=595 \mathrm{~K}$ で $T_{v}$ $=3436 \mathrm{~K}$ の場合について，（8)式より計算した $\mathrm{N}_{2}$ の 2nd positive systemバンド $(0,2)$ 系列のスペクトル

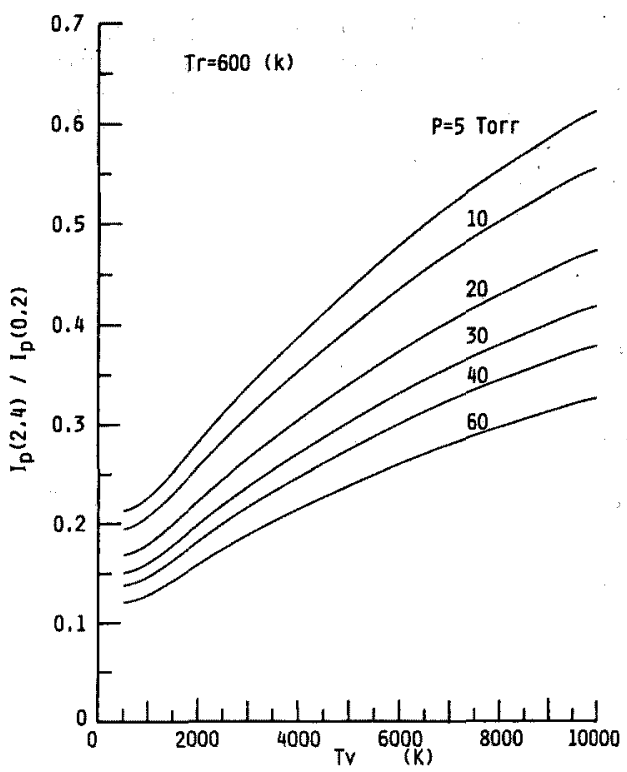

図 5 気体圧力をパラメータにした $I_{p}(2,4) / I_{p}(0,2)-T_{r}$ 特性

Fig. 5. $I_{p}(2,4) / I_{p}(0,2)$ ratio as a function of vibrational temperature, with gas pressure as parameter.

強度分布である。 $C^{3} \Pi u\left(v^{\prime}\right) \rightarrow B^{3} \Pi g\left(v^{\prime \prime}\right)$ 遷移の各バン

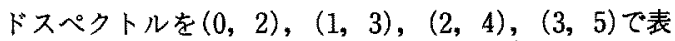
示するとき，各々のスペクトル強度分布のピーク值 は, $3,805 \AA, 3,755.5 \AA$, 3,710.6 ̊̊ そして $3,671.8 \AA$ の波長の位置に現れる。

一方, 図 4 は $P=30$ Torr で放電電流が $2 \mathrm{~mA}$ の直 流グロー放電の負グローで実測した図 3 に対応するス ペクトル強度分布である。このとき， $T_{v}$ は後述する 方法で, 同一の $P$ と $T$ ，の条件下での解析と実測の 各々の $(2,4)$ のスペクトル強度のピーク值 $I_{p}(2,4)$ と $(0,2)$ ののピーク值 $I_{p}(0,2)$ の比が 0.237 で等しく なることから決定される。これらの両図から，T，と $T_{v}$ そして $P$ が各々同一の值であれば，解析と実測の $(0,2)$ 系列のスペクトル強度分布にはよい一致が認め られることがわかる。なお，図 3 と図 4 を敩密に比較 すると， $I_{p}(1,3) / I_{p}(0,2)$ と $I_{p}(3,5) / I_{p}(0,2)$ の解析と実 測の比は各々 $+12 \%$ と $17 \%$ 相違がある。

以上の結果から，簡便にしかも精度良く $T_{v}$ を診断 する方法は， $T_{r}, T_{v}$ そして $P$ のうつハハラメータに 対して $I_{P}(2,4) / I_{\rho}(0,2)$ 比の理論值と実測值の比較か゚ 考えられる。

図 5 は $T_{r}=600 \mathrm{~K}$ 一定て，Pを変化した場合の $I_{p}(2,4) / I_{p}(0,2)-T_{v}$ 曲線を示したものである。また, 


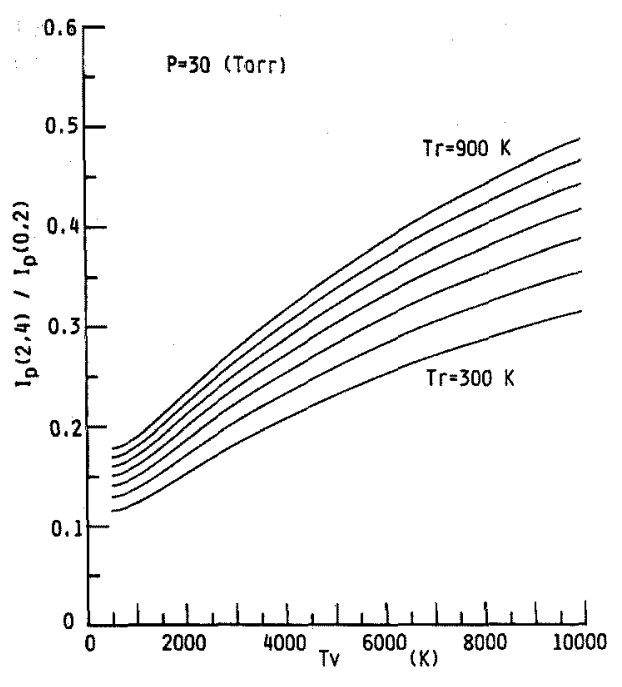

図 6 回転温度をパラメータにした $I_{p}(2,4) / I_{p}(0,2)-T_{v}$ 特性

Fig. $6 . \quad I_{p}(2,4) / I_{p}(0,2)$ ratio as a function of vibrational temperature, with rotational temperature as parameter.

図 6 は $P=30$ Torr 一定で $T_{r}$ を $300 \sim 900 \mathrm{~K}$ の間で $100 \mathrm{~K}$ ごとに変化した場合の $I_{p}(2,4) / I_{p}(0,2)-T_{v}$ 曲線 を示したものである。これらの図から，Tvの決定に 用いられる $I_{p}(2,4) / I_{p}(0,2)$ 比は，Pと $T_{T}$ に顕著に依 存することがわかる。従って，Toの診断には，本研 究でも用いた $\mathrm{N}_{2} の 2$ 2nd positive systemバンド $(0,2)$ の回転スペクトル強度分布による精密な $T_{r}$ の計測(3) が不可欠である。そこで，具体的に $T_{v}$ を計測する 場合, 図 5 や図 6 で与えられるような校正曲線の解析 式 $\left(\Delta T_{r}=50 \mathrm{~K} こ ゙ と\right)$ をマイクロンピュータに記憶 してお゙き，次に実測した $T_{r}$ と $I_{p}(2,4) / I_{p}(0,2)$ 比の入 カデータをこの解析式と比較する演算処理して, 直ち に $T_{v}$ を導出するシステムを構成した。

ところで，今回開発した $T_{v}$ 診断では，同一放電条 件下，例えば $4,000 \mathrm{~K}$ の值に対して $100 \mathrm{~K}$ 以内の愦差 で再現性良く $T_{v}$ を決定できることを確認している。 また， $T r$ の測定誤差は $T_{v}$ の誤差に影響を与えるこ とに注意しなければならない。なお，P=5〜60 Torr, $T_{r}=400 \sim 900 \mathrm{~K}, T_{v}=500 \sim 7,000 \mathrm{~K}$ の広範囲 の放電条件での今回の診断結果から，その計測誝差は 6\%程度であることがわった。

\section{3. 負グロー中の回転温度と振動温度}

負グローを含む陰極シース領域の研究 ${ }^{(12)(13)}$ は, 放 電維持機構と関連した電子エネルギー分布に関心がも

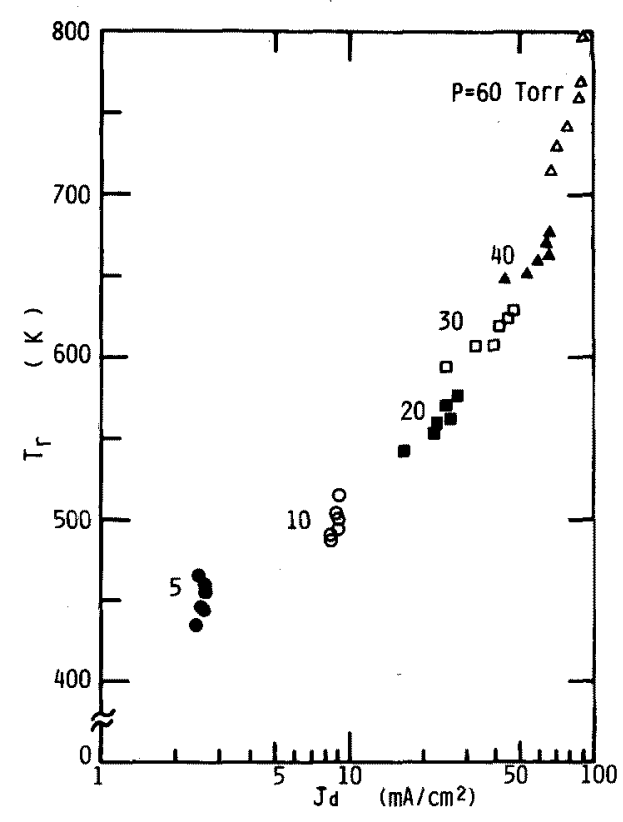

図 7 気体圧力をパラメータとした負グロー の回転温度-放電電流密度特性

Fig. 7. Rotational temperature as a function of discharge current density for negative glow, with pressure as parameter.

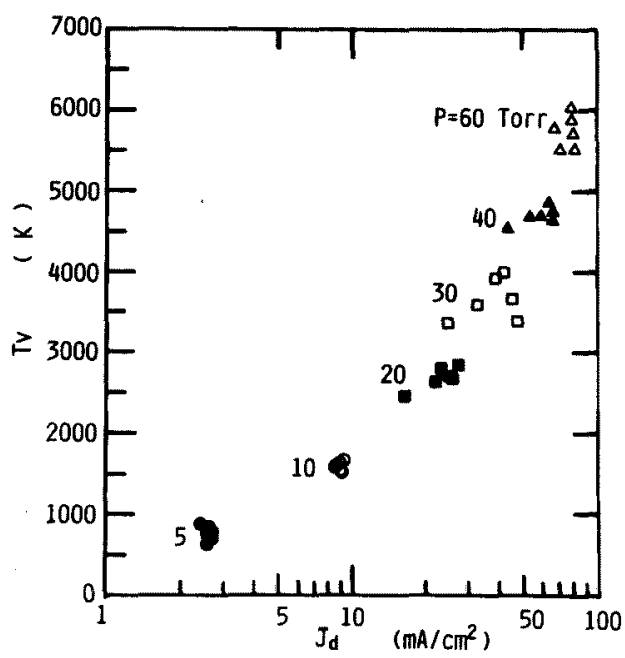

図 8 気体压力をパラメータとした負グロー の振動温度一放電電流密度特性

Fig. 8. Vibrational temperature as a function of discharge current density for negative glow, with pressure as parameter.

たれる。また， $\mathrm{N}_{2}$ ガスの著者らの研究 ${ }^{(2)(4)}$ によれば, $T_{r}, T_{v}$ の空間的変化も顕著であることを指摘してい る。このように負グロー(NG)を含む陰極シース領域 
は，多くの複雑な粒子衝突を生じる放電プラズマで ある。

ここでは, $\mathrm{N}_{2}$ ガス直流グロー放電の NGでの $T_{r}$ と $T_{v}$ を今回の分光学的診断で計測した結果を示す。 計測対象放電プラズマは, $P=5 \sim 60$ Torr, 放電電流 $I=2 \sim 7 \mathrm{~mA}$ そしてギャップの長さの $1 \mathrm{~cm}$ の直径 5 $\mathrm{cm}$ のステンレス鋼製平行平板ギャップの非定常拡散 グロー放電相から定常収縮グロー放電相への相転移 後 ${ }^{(2)}$ 関するものである。計測点は $\mathrm{NG} の \mathrm{~N}_{2}$ 2nd Positive system バンド $(0,2)$ のスペクトル強度の最 大值の位置であり, 放電半径 $r$ は, このスペクトル の径方向強度が中心部の約 10 分の 1 に低下する距離 とした。この放電半径の測定結果の一例を示すと, $P$ $=30$ Torr の $r$ は, $I=2 \sim 7 \mathrm{~mA}$ の範囲で $I$ に比例し て $0.17 \sim 0.21 \mathrm{~cm}$ に増大した。

図 7 と図 8 は， $P$ をパラメー夕とした放電電流密 度 $J_{d}\left(=I / \pi r^{2}\right)$ に対する $T r$ と $T_{v}$ の変化を示す。な お, 各 $P$ の值での 6 個のデータは, $I$ が $2 \sim 7 \mathrm{~mA}$

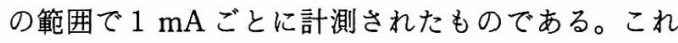
らの図からは, $T_{r}$ は $J_{d}$ と $P$ の増大に対して室温よ り相当に高い値へ上昇し，また $T_{v} に も$ 同様な傾向が 認められる。同一範囲の放電電流下の $T_{r}$ と $T_{v}$ は, $P$ が高いものほど電子拡散の抑制と気体加熱効果に よって収縮した NGで大きくなることがわかる。従 って, NGを含む陰極したシース領域の解明には, 電 子のエネルギー分布のみではなく， $T_{r}$ と $T_{v}$ の情 報 ${ }^{(7)(8)}$ が放電収縮機構とも関係して極めて重要となる ことが明らかとなった。

\section{4. まと め}

数 Torr 以上の $\mathrm{N}_{2}$ ガス直流グロー放電は, 放電チ ヤネルの著しく収縮した発光形態を与える。収縮機構 の放電プラズマからの検討には，そのプラズマの診断 技術の確立が不可欠である。特に， $\mathrm{N}_{2}$ ガスに扔いて は, 振動励起分子の衝突反応過程が電子の輸送パラメ 一夕を大きく左右する。今回の研究は,この振動励起 分子のエネルギ状態を振動温度を測定することによっ て把握することを目的に計画された。

本研究では，まず $\mathrm{N}_{2}$ の 2nd positive system バン ド $(0,2)$ 系列の放射スペクトル強度分布に与える気体 圧力, 回転温度 $(\fallingdotseq$ 気体温度 $)$ そして振動温度の効果 を数值解析で明らかにした。次に，その解析結果と実 測したスペクトル強度分布との比較検討から，気体圧 力と気体温度を考慮した精密な振動温度の計測法を提 案した。そして, 放電電流が $2 \sim 7 \mathrm{~mA}$ で, 数 Torr 以上の収縮した $\mathrm{N}_{2}$ ガス直流グロー放電の負グロー中
の回転温度と振動温度の診断に今回の方法を適用し た。その結果, 負グロー中の回転温度と振動温度は, 気体圧力と放電電流密度の上昇によって高くなること が判明した。なお，振動温度のこの診断法での測定誤 差は，同一放電条件下で約 6\%である。

最後に, 本研究の解析に助言をいただいた本学計算 機センターの関係各位ならびに実験に協力された本学 大学院生仲程 拓君および卒論生のみなさんに感謝 します。

(平成 2 年 2 月 5 日受付, 同 2 年 5 月 25 日再受付)

\section{文献}

(1) J. Loureio \& M. Ferria: J. Phys. D; Appl. Phys., 22, 67 (1989)

(2) 西嶋, 美山, 常安: 電学論, A, 104, 153 (昭 59-3)

(3) 西嶋 - 加峯- 常安: 福岡大学工学集報, No. 41, 33 (昭 63)

(4) 西嶋, 加峯, 水田: 電学論, A, 109, 176 (平元-4)

（5）西嶋, 美山, 常安: 福岡大学工学集報, No. 29, 19 (昭 57)

(6) R. Bleekrode: IEEE J. Quantum Electronics, QE-5, 5 ? (1969)

(7) W. Benesch, J. T. Vanderslice, et al. : Astrophys, J., 143, 236 (1966)

(8) I. Gallimberti, J. K. Hepworth \& R. C. Klewe : J. Phys. D ; Appl. Phys., 7. 880 (1974)

(9) 藤岡 編：分光学, p. 289 (昭 42) 講談社

(10) D. M. Phillips: J. Phys. D ; Appl. Phys., 8. 507 (1975)

(11) J. Loureiro \& C. M. Ferreira : J. Phys, ; Appl. Phys., 19, 17 (1986)

(12) R. J. Carman: J. Phys. D ; Appl. Phys., 22, 55 (1989)

(13) B. Shi, G. J. Fetzer, et al. : IEEE J. Quant. Electronics, 25, 948 (1989)

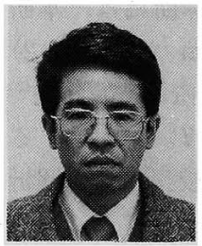

\section{西 嶋 喜代人（正員）}

昭和 25 年 3 月 3 日生。 47 年 3 月 関東学院大学電気工学科卒業。 49 年 3 月慶応義塾大学大学院修士課程 修了。53 年 3 月九州大学大学院工 学研究科博士課程単修退, 同年 4 月同大学工学部助 手。5 5 年 4 月福岡大学工学部電気工学科講師, 57 年 4 月同大学助教授, 現在に至る。 59 年 4 月 60 年 3 月英国・ストラスクライド大学客員研究員。工学博士。 主として, 長ギャップ放電および低気圧放電の研究に 従事。照明学会, IEEE 会員。

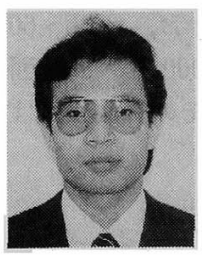

\section{水 田 佳 男 (正員)}

昭和 38 年 5 月 9 日生。平成 2 年 3 月福岡大学大学院工学研究科電気 工学専攻修士課程修了。同年 4 月 (株)マツダ入社, 現在に至る。主と して, $\mathrm{N}_{2}$ ガス直流グロー放電の分光学的プラズマ診 断法の開発に従事。 